sinh chiếm $6,9 \%$. Học sinh nữ $(7,5 \%)$ có tỷ lệ suy dinh dưỡng cao hơn học sinh nam $(6,1 \%)$.

- Tỷ lệ thừa cân, béo phì chiếm 13,8\%. Trong đó tỷ lệ thừa cân, béo phì ở học sinh nam $(17,9 \%)$ cao hơn rõ rệt ở học sinh nữ (10,6\%).

\section{KHUYẾN NGH!}

- Tăng cường các biênn pháp can thiêp nhằm cải thiện tình trạng dinh dương cho trè em lứa tuổi học đường nói chung và lứa tuổi học sinh trung học phổ thông.

- Cân xây dựng chế độ ăn cân đối, hợp lý đảm bảo cung cấp đủ các chất dinh dưỡng sinh năng lượng (protein, lipid và glucid) và không sinh năng lượng (vitamin và chất khoáng) cho các em học sinh.

\section{TÀI LIÊU THAM KHẢO}

1. Lê Trân Tuấn Anh, Nguyễn Thị Thắm, Nguyễn Đức Dương, Nguyền Quang Hùng (2021), Thực trạng suy dinh dưỡng thể thấp còi và một số yếu tố liên quan ở một số trường trung học phổ thông tại Hải Phòng năm 2019, Tạp chí Y học dự phòng tập 31 , số 1 , tr. 66 - 71 .

2. Nguyện Nhật Cảm, Nguyễn Thị Thi Thơ, Nguyển Thi Kiêu Anh (2017), Tỷ lê suy dinh dưỡng thể gày còm và một số yêu tố liên quan của học sinh từ 11 - 17 tuổi tại thành phố Hà Nội, Tạp chí Y hoc dư phòng, tâp 27, số 7, tr. 120 - 12'9.

3. Lê Thị Hợp, Huỳnh Nam Phương (2011), Thống nhất về phương pháp đánh giá tình trạng dinh dưỡng bằng nhẩn trắc học, Tạp chí Dinh dưỡng và Thực phẩm, 7(2) tr. 28 - 29 .

4. Trân Thị Minh Hanh, vũ Quỳnh Hoa và Đỗ Thi Ngoc Diệp (2012), Diễn tiến tình trạng dinh dưỡing và tăng trướng hoc sinh Tp. HCM 20022009, Tạp chí Dinh dưỡng và Thực phẩm; 8(4): tr. $17-26$.

5. Nguyễn Thị Thắm, Lê Trân Tuấn Anh, Nguyễn Đức Dương, Hoàng Thị Giang, Nguyến Quang Hùng (2021), Thực trạng thữa cân, béo phì và một số yếu tô liên quan ở học sinh một số trường phổ thông trung học tai Hải Phòng năm 2019 2020, Tạp chí Y học dự phòng, tập 31, sô 1, tr. 148 - 154.

\title{
PHÂN TíCH KIẾN THỨC, THÁI ĐỘ VÀ THƯC HÀNH CỦA NHÂN VIÊN Y TẾ VỀ BÁO CÁO PHẢN ỨNG CÓ HẠI CỦA THUỐC TẠI MộT SỐ BỆNH VIÊ̂N ĐA KHOA NĂM 2020
}

\author{
Trần Thị Lan Anh ${ }^{1}$, Trần Lê Vương Đại ${ }^{2}$, Vũ Phương Thảo ${ }^{1}$, \\ Trần Ngân Hà ${ }^{1}$, Bùi Thị Ngọc Thực ${ }^{2}$, Nguyễn Thu Minh ${ }^{2}$, \\ Nguyễn Quỳnh $\mathrm{Hoa}^{2}$, Nguyễn Hoàng Anh ${ }^{1,2}$. Trần Nhân Thắng ${ }^{2}$
}

\section{TÓM TẮT}

Mục tiêu: Nghiên cứu được thực hiện tại 3 bệnh viện đảa khoa ở những vùng địa lý khác nhau với cơ cấu tổ chức và triển khai hoạt động Cảnh giác Dược ở các mức độ khác nhau nhằm phân tích thực trạng kiến thức, thái độ và thực hành của NVYT về hoạt động báo cáo phản ứng có hại của thuốc. Đối tượng và phương pháp nghiên cứu: Nghiên cứu mồ tả cắt ngang, thu thập thông tin kiến thức, thái độ và thực hành của NVYTं về báo cáo $A D R$ thông qua phỏng vấn bằng bô câu hỏi, được thu thâp từ tháng 10 đến tháng 11 năn 2020. Kết quả: Hầu hết nhân viên y tế đều có kiến thức đầy đủ vê $A D R$ và cơi hoạt động báo cáo ADR là một trong những hoạt động chuyên môn quan trọng. Mặc dù có $73,48 \%$ NVY̛T đã từng gặp ADR song chỉ có 49,08\% NVYT đã từng báo cáo ADR. Hơn $40 \%$ số NVYT khảo sát không biết báo cáo và không báo cáo các phản ứng nhẹ. Kết luận: Phần lớn

${ }^{1}$ Trường Đại học Dược Hà Nội

${ }^{2}$ Khoa Dước, Bênh viên Bach Mai

Chịu trách nhiệm chính: Trần Thị Lan Anh

Email: tranlananh7777@gmail.com

Ngày nhận bài: 4.3.2021

Ngày phản biên khoa hoc: 26.4 .2021

Ngày duyệt bài: 7.5.2021 các NVYT có thái độ và kiến thức tốt về báo cáo $A D R$ song tỷ lê báo cáo vẫn còn thấp. Đào tao tâp huấn về $A D R$ và kết hợp nhiều hình thức báo cáo là giải pháp để nâng cao hiệu quả hoạt động boá cáo ADR.

\section{SUMMARY \\ KNOWLEDGE, ATTITUDE AND PRACTICES (KAP) OF HEALTHCARE PROFESSIONALS IN THREE GENERAL HOSPITALS TOWARDS ADVERSE DRUG REACTION (ADR) REPORTING IN 2020}

Objective: The purpose of this study was to analyze the knowledge, attitudes, and practices of healthcare professionals (HCPs) towards adverse drug reaction reporting in three general hospitals. Methods: cross-sectional study was conducted from Oct to Nov 2020. Data were collected through selfadministered questionnaires with Google form. Results: Most HCPs have positive knowledge of ADR and consider ADR reporting to be one of the most important professional activities. Although $73.48 \%$ of HCPs have ever met ADR, only $49.08 \%$ have ever reported ADR. Of the respondents, over $40 \%$ did not know how to report and mild reactions that are not worth reporting, these are main factors contributing to non - reporting of ADRs. Conclusion: Most HCPs 
have the positive awareness and attitude towards ADR reporting but the actual frequency of ADR reporting was low. To improve the quantity and quality of ADR reports, training and to combine reporting methods was showed in our study.

Keywords: ADR reporting, Knowledge, Attitude, Practice.

\section{I. ĐĂT VẤN ĐỀ}

Báo cáo phản ứng có hại của thuốc (Adverse Drug Reactions - $A D R$ ) được coi là một trong những hoạt động chuyên môn quan trọng để phát hiện các tín hiêu an toàn thuốc, là bước đầu tiên của quy trình Cảnh giác Dược. Tại Việt Nam, Hướng dẫn Quốc gia về Cảnh giác Dược lần thứ nhất được Bộ Y tế ban hành năm 2015 là hướng dẫn chuyên môn chính thức đầu tiên quy định phạm vi, quy trình hoạt động, vai trò của các thành phần trong hệ thống và hướng dẫn chi tiết triển khai hoạt động Cảnh giác Dược tại Việt Nam, đặc biệt là hệ thống báo cáo tự nguyện về phản ứng có hại của thuốc. Tuy nhiên, tình trạng báo cáo thiếu và kém chất lượng vấn còn phổ biến [4]. Các nghiên cứu trước đây đã chỉ ra rằng kiến thức, thái độ của nhân viên y tế (NVYT) về báo cáo $A D R$ có ảnh hưởng đên hoat động báo cáo ADR của NVYT $[5,6]$. Hướng dấn Cảnh giác dược ra đời đã tác động đên hoạt động báo cáo $A D R$ tại các bệnh viện như thế nào đặc biệt là kiến thức, thái độ và thực hành của NVYT đối với hoạt động này. Vì vậy, nghiên cứu này được thực hiện tại 3 bệnh viện đa khoa ở những vùng địa lý khác nhau với cớ cấu tổ chức và triển khai hoạt động Cảnh giác Dược ở các mức độ khác nhau nhằm phân tích thực trạng kiến thức, thái độ và thực hành của NVYT về hoạt động báo cáo phản ứng có hại của thuốc.

\section{II. ĐỐI TƯợNG VÀ PHƯƠNG PHÁP NGHIÊN CỨU}

Đối tượng nghiên cứu. Các cán bộ y tế bao gồm bác sĩ, điều dưỡng đang làm việc tại các Khoa Lâm sàng của 3 bệnh viện: Bệnh viện Bạch Mai, Bệnh viện Trung ương Huế và Bệnh viện Nhân dân Gia Định. Các bệnh viện được mã hoá với ký hiệu: BV 1, BV 2 và BV 3.

Phướng pháp nghiên cứu. Nghiên cứu mô tả cắt ngang, thu thập thông tin kiến thức, thái độ và thực hành của NVYT về báo cáo $A D R$ thông qua phỏng vấn bằng bộ câu hỏi.

Mẫu nghiên cứu. Dựa theo tỷ lệ nhân viên $y$ tế hiểu đầy đủ về $A D R$ sau can thiểp chiếm tỷ lệ 49,9\% [5], cõ mẫu cần thiết tại mối bệnh viện là $\mathrm{n}=235$.

Phương pháp thu thập số liệu. Sử dụng bộ câu hỏi thu thập số liệu dưới dạng Google forms, thời gian từ tháng 10/2020 đến tháng
11/2020. Mỗi khoa, phòng của các bệnh viện được gửi Phiếu Hướng dẫn khảo sát, bao gồm: Khảo sát qua mã QR - Code hoặc Truy cập trực tiếp vào link Docs Google.

- Bộ câu hỏi được thiết kế bao gồm 2 loại câu hỏi: nhiều lựa chọn và Có/Không.

- Bộ câu hỏi đảm bảo bí mật tên người trả lời, không phân biệt giữa các khoa.

- Cấu trúc bộ câu hỏi gồm 4 nội dung: (1) Kiến thức của NVYT về $A D R$ và báo cáo $A D R ;(2)$ Thái độ của NVYT về báo cáo ADR; (3) Thực hành báo cáo $A D R$ của NVYT; (4) Biện pháp để thúc đẩy hoạt động báo cáo ADR

- Đáp án đúng được xác định dựa trên định nghĩa của WHO và các quy định được ban hành trong các văn bản hướng dần của Bộ Y tế $[1,2,3]$.

Xử lý và phân tích số liệu. Xử lý trên toàn bộ số câu hỏi điền đầy đủ thổng tin về trình độ chuyên môn và trả lời toàn bộ các câu hỏi.

Số liệu được mã hóa, nhập liệu và xử lý bằng chương trình Microsoft Excel 2007. Phân tích số liệu bằng phần mềm SPSS 20. Với biến định tính (tính tần suất, tỷ lệ \%) sử dụng test Chi square hoặc test Fisher Square để so sánh sự khác biệt giữa các bệnh viện.

\section{KẾT QUẢ NGHIÊN CỨU}

Kiến thức vê ADR và báo cáo ADR của NVYT

Nhận thức về ADR. Khảo sát nhận thức của NVYT về định nghĩa phản ứng có hại của thuốc (ADR) thu được kết quả như hình 1 :

$$
\text { Tỷ lệ NVYT nhận thức đầy đủ định nghĩa ADR theo WHO }
$$

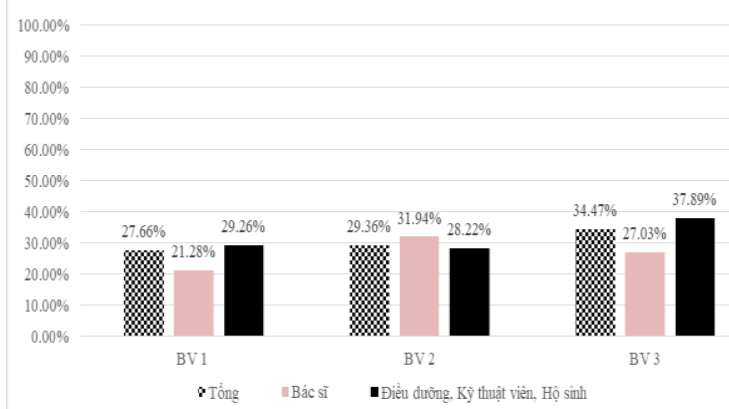

Hình 1: Tỷ lệ nhận thức đúng của cán bộ y tế về ADR theo định nghĩa của WHO

Số lượng cán bộ y tế hiếu đầy đủ theo định nghĩa $A D R$ theo WHO chiếm tỷ lệ thấp. Tại cả 3 bệnh viện, tỷ lệ NVYT trả lời đúng cao nhất chỉ đạt $34,47 \%$.

Nhận thức về hoạt động báo cáo ADR. NVYT tại 3 bệnh viện nhận thức rằng các thuốc lưu hành trên thị trường là không an toàn chiếm tỷ lệ khá cáo $(81,28 \%-91,06 \%)$. 
Bảng 2: Nhận thức về hoạt động báo cáo ADR của NVYT tại các bệnh viện

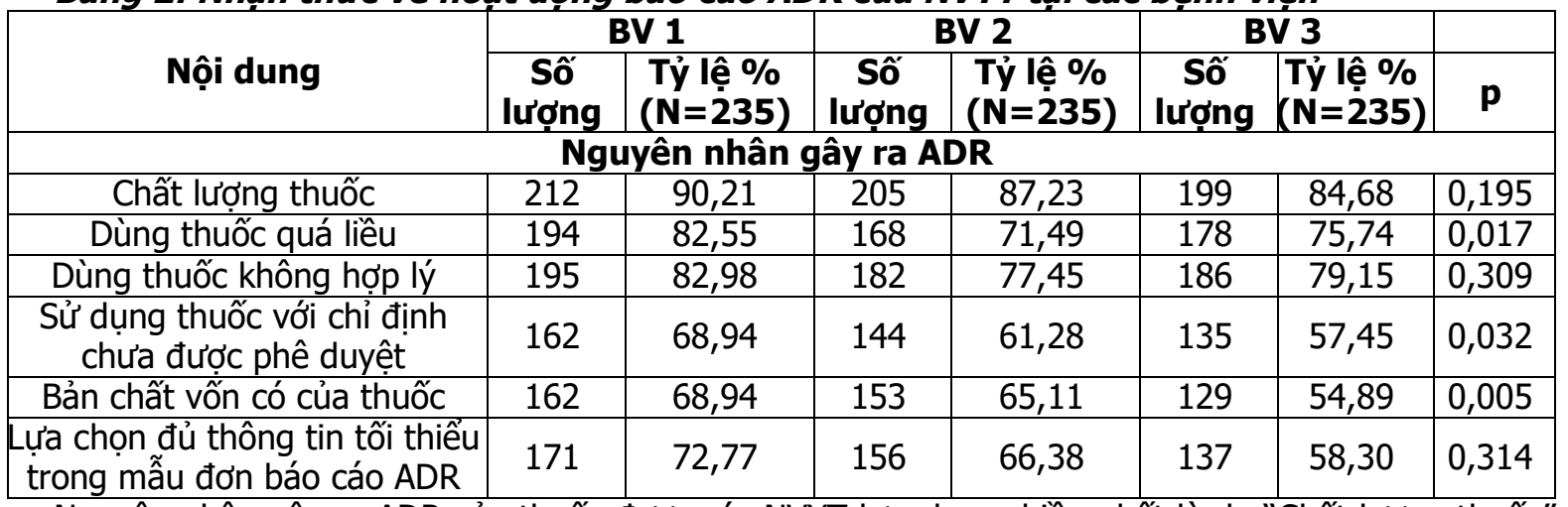

Nguyên nhân gây ra ADR của thuốc được các NVYT lựa chọn nhiều nhất là do "Chất lượng thuốc" với tỷ lệ từ 84,68\% - 90,21\%. Bên cạnh các nguyên nhẩn theo kết quả thu thập được, "Cớ địa bệnh nhân" và "Tương tác thuốc" là các lý do mà NVYT đề cập tới.

Trên $50 \%$ các NVYT trả lời đúng về các thông tin cần điền trong mẫu báo cáo $A D R$, tỷ lệ này cao nhất ở BV $1(72,77 \%)$.

Thái độ của NVYT vê hoạt động báo cáo ADR

Hầu hết các NVYT được khảo sát cho rằng hoạt động báo cáo ADR là quan trọng (99,86 \%).

Bảng 3: Thái độ của NVYT về báo cáo ADR

\begin{tabular}{|c|c|c|c|c|c|c|c|}
\hline \multirow[b]{2}{*}{ Nội dung } & \multicolumn{2}{|c|}{ BV 1} & \multicolumn{2}{|c|}{ BV 2} & \multicolumn{2}{|c|}{ BV 3} & \multirow[b]{2}{*}{ p } \\
\hline & $\begin{array}{c}\text { Số } \\
\text { lượng }\end{array}$ & $\begin{array}{l}\text { Tỷ lệ \% } \\
(\mathbf{N}=\mathbf{2 3 5})\end{array}$ & $\begin{array}{c}\text { Số } \\
\text { Iượng }\end{array}$ & $\begin{array}{l}\text { Tỷ lệ \% } \\
(\mathbf{N}=\mathbf{2} 35)\end{array}$ & $\begin{array}{c}\text { Số } \\
\text { lượng }\end{array}$ & $\begin{array}{l}\text { Tỷ lệ \% } \\
(\mathbf{N}=\mathbf{2} 35)\end{array}$ & \\
\hline \multicolumn{8}{|c|}{ Vai trò của báo cáo ADR } \\
\hline $\begin{array}{c}\text { Chia sẻ thông tin ADR với } \\
\text { đồng nghiệp }\end{array}$ & 217 & 92,34 & 206 & 88,03 & 185 & 78,72 & 0,000 \\
\hline $\begin{array}{l}\text { Đảm bảo an toàn cho } \\
\text { bệnh nhân }\end{array}$ & 222 & 94,47 & 221 & 94,44 & 219 & 93,19 & 0,841 \\
\hline $\begin{array}{l}\text { Xác định vấn đề liên quan } \\
\text { đến an toàn thuốc }\end{array}$ & 207 & 88,09 & 213 & 91,03 & 194 & 82,55 & 0,028 \\
\hline \multicolumn{8}{|c|}{ Khó khăn của NVYT khi báo cáo ADR } \\
\hline Mấu báo cáo phức tạp & 73 & 31,06 & 69 & 29,36 & 74 & 31,49 & 0,869 \\
\hline Khó xác định thuốc nghi ngờ & 94 & 40,00 & 95 & 40,43 & 136 & 57,87 & 0,000 \\
\hline Không có thời gian & 15 & 6,38 & 35 & 14,89 & 51 & 21,70 & 0,000 \\
\hline $\begin{array}{l}\text { Khó xác định mức độ } \\
\text { nghiêm trọng của phản } \\
\text { ứng có hại của thuốc }\end{array}$ & 117 & 49,79 & 100 & 42,55 & 130 & 55,32 & 0,021 \\
\hline Thiếu kiến thức lâm sàng & 37 & 15,74 & 18 & 7,66 & 48 & 20,43 & 0,000 \\
\hline Không có khó khăn nào & 53 & 22,55 & 64 & 27,23 & 23 & 9,79 & 0,000 \\
\hline \multicolumn{8}{|c|}{ Nguyên nhân NVYT chưa thực hiện báo cáo } \\
\hline $\begin{array}{l}\text { Viêc báo cáo không ảnh } \\
\text { hưởng đến phác đồ điều trị }\end{array}$ & 33 & 14,04 & 35 & 14,89 & 47 & 20,00 & 0,167 \\
\hline Mất thời gian & 71 & 30,2 & 75 & 31,91 & 91 & 38,72 & 0,118 \\
\hline Thiếu kinh phí & 11 & 4,68 & 18 & 7,66 & 20 & 8,51 & 0,230 \\
\hline $\begin{array}{l}\text { Phản ứng này đã được } \\
\text { biết quá rõ }\end{array}$ & 42 & 17,87 & 42 & 17,87 & 34 & 14,47 & 0,521 \\
\hline Không có săn mâu báo cáo & 49 & 20,85 & 51 & 21,70 & 79 & 33,62 & 0,002 \\
\hline Không biết cách báo cáo & 88 & 37,45 & 70 & 29,79 & 114 & 48,51 & 0,000 \\
\hline $\begin{array}{l}\text { Phản ứng nhe không đáng } \\
\text { để báo cáo }\end{array}$ & 106 & 45,11 & 98 & 41,70 & 91 & 38,72 & 0,303 \\
\hline Sợ bị quy kết trách nhiệm & 68 & 28,94 & 76 & 32,34 & 70 & 29,79 & 0,705 \\
\hline Khác & 13 & 5,53 & 14 & 5,96 & 7 & 2,98 & 0,265 \\
\hline
\end{tabular}


Khi đề câp tới vai trò của báo cáo ADR, các lý do được NVYT lựa chọn với tỷ lệ cao (khoảng $80 \%$ ) bao gồm "Đảm bảo an toàn cho người bệnh", "Chia sẻ thông tin ADR với đồng nghiệp" và "Xác định vấn đề liên quan đến an toàn thuốc". Tuy nhiên họ cũng đề cập tới khó khăn nhiều nhất là "Khó xác định thuốc nghi ngờ" và "Khó xác định mức độ nghiêm trọng của ADR", mức độ này có sự khác biệt giữa 3 bệnh viện.

"Phản ứng nhẹ không đáng để báo cáo" $(45,11 \%$ ở $\mathrm{BV} 1$ và $41,70 \%$ ở $\mathrm{BV} 2)$ và "Không biết cách báo cáo" $(48,51 \%$ ở BV 3$)$ là các lý do nhân viên y tế không báo cáo phản ứng có hại.
Ngoài ra, NVYT cũng đề cập tới một số lý do như "Khối lượng công việc nhiều nên hay quên báo báo", "Lười chưa có trách nhiêm".

Thực hành của NVYT về hoạt động báo cáo ADR

Trong số 705 NVYT tham gia trả lời bộ câu hỏi, 346 NVYT đã từng báo cáo ADR tương ứng $49,08 \%$ và 521 NVYT trả lời đã biết quy trình báo cáo ADR tại bệnh viện.

Khảo sát về thực hành báo cáo ADR của 521 NVYT (tương ứng tại các bệnh viện là 165 NVYT tại BV 1, 182 NVYT tại BV 2 và 174 NVYT tại BV 3), chúng tôi thu được kết quả ở bảng 4:

Bảng 4: Thời gian thực hiện và nơi gửi báo cáo ADR

\begin{tabular}{|c|c|c|c|c|c|c|c|}
\hline \multirow[b]{2}{*}{ Nội dung } & \multicolumn{2}{|c|}{ BV 1} & \multicolumn{2}{|c|}{ BV 2} & \multicolumn{2}{|c|}{ BV 3} & \multirow[b]{2}{*}{$\mathbf{p}$} \\
\hline & $\begin{array}{c}\text { Số } \\
\text { lượng }\end{array}$ & $\begin{array}{l}\text { Tỷ lề \% } \\
(\mathrm{N}=\mathbf{1 6 5})\end{array}$ & $\begin{array}{c}\text { Số } \\
\text { Iượng }\end{array}$ & $\begin{array}{c}\text { Tỷ lệ \% } \\
(\mathbf{N}=\mathbf{1 8 2})\end{array}$ & $\begin{array}{c}\text { Số } \\
\text { lượng }\end{array}$ & $\begin{array}{l}\text { Tỷ lề \% } \\
(\mathrm{N}=174)\end{array}$ & \\
\hline \multicolumn{8}{|c|}{ Thời gian gửi báo cáo } \\
\hline Đối với báo cáo nghiêm trọng & 160 & 96,97 & 178 & 97,80 & 165 & 94,83 & 0,288 \\
\hline $\begin{array}{c}\text { Đối với báo cáo không } \\
\text { nghiêm trọng }\end{array}$ & 61 & 36,97 & 11 & 6,04 & 41 & 23,56 & 0,000 \\
\hline \multicolumn{8}{|c|}{ Địa điểm gửi báo cáo } \\
\hline $\begin{array}{l}\text { Đơn vị Thông tin thuốc- } \\
\text { Dược lâm sàng }\end{array}$ & 154 & 93,33 & 150 & 82,42 & 153 & 87,93 & 0,008 \\
\hline \begin{tabular}{|c|} 
Trung tâm Quốc gia hoặc \\
khu vực về Thông tin thuốc \\
và Theo dõi phản ứng có hại \\
của thuốc \\
\end{tabular} & 19 & 11,52 & 34 & 18,68 & 29 & 16,67 & 0,247 \\
\hline \multicolumn{3}{|c|}{ 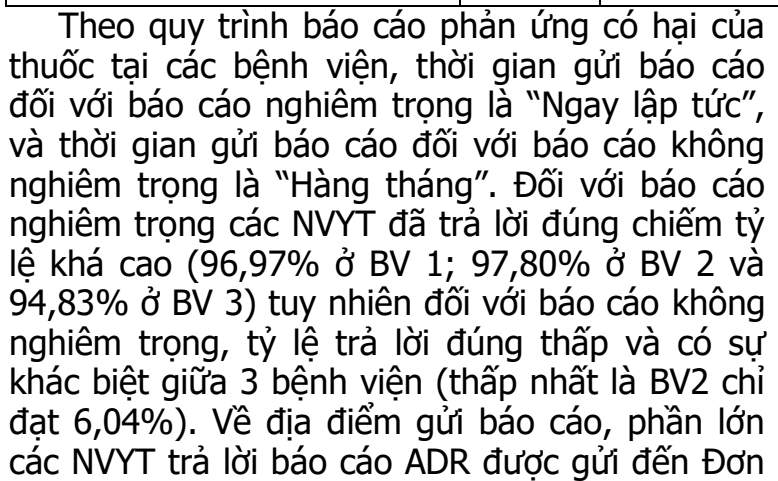 } & \multicolumn{5}{|c|}{ 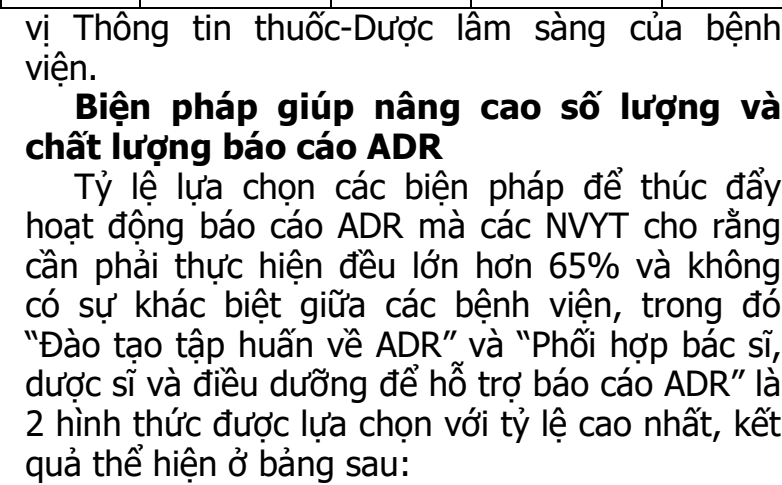 } \\
\hline
\end{tabular}

Bảng 5: Biện pháp giúp nâng cao số lượng và chât lượng báo cáo ADR

\begin{tabular}{|c|c|c|c|c|c|c|c|}
\hline \multirow[b]{2}{*}{ Nội dung } & \multicolumn{2}{|c|}{ BV 1} & \multicolumn{2}{|c|}{ BV 2} & \multicolumn{2}{|c|}{ BV 3} & \multirow[b]{2}{*}{$\mathbf{p}$} \\
\hline & \begin{tabular}{|c|} 
Số \\
lượng
\end{tabular} & $\begin{array}{l}\text { Tỷ lệ \% } \\
(\mathbf{N}=\mathbf{2 3 5})\end{array}$ & $\begin{array}{c}\text { Số } \\
\text { Iượng }\end{array}$ & \begin{tabular}{|l|} 
Tỷ lệ \% \\
$(\mathbf{N}=\mathbf{2} 35)$ \\
\end{tabular} & $\begin{array}{c}\text { Số } \\
\text { lượng }\end{array}$ & $\begin{array}{l}\text { Tỷ lệ \% } \\
(\mathbf{N}=\mathbf{2 3 3 5})\end{array}$ & \\
\hline $\begin{array}{l}\text { Đào tạo và tập huấn về ADR cho } \\
\text { cán bộ y tế }\end{array}$ & 211 & 89,79 & 211 & 89,79 & 217 & 92,34 & 0,548 \\
\hline $\begin{array}{l}\text { Phối hợp bác sĩ, dước sĩ và điều } \\
\text { dưỡng để hỗ trợ báo cáo ADR }\end{array}$ & 210 & 89,36 & 215 & 91,49 & 212 & 90,21 & 0,734 \\
\hline $\begin{array}{c}\text { Gửi phản hồi về kết quả đánh giá } \\
\text { ADR đến cán bộ y tế }\end{array}$ & 173 & 73,62 & 175 & 74,47 & 159 & 67,66 & 0,202 \\
\hline $\begin{array}{c}\text { Có cơ chế quy định và quy trình } \\
\text { hướng dẫn báo cáo ADR trong } \\
\text { bệnh viện }\end{array}$ & 176 & 74,89 & 179 & 76,17 & 170 & 72,34 & 0,625 \\
\hline
\end{tabular}




\begin{tabular}{|c|c|c|c|c|c|c|c|}
\hline $\begin{array}{c}\text { Có nhiều kênh, hình thức báo cáo } \\
\text { như báo cáo qua điện thoaai, qua } \\
\text { mang internet, qua email bền cạnh } \\
\text { cách thông thường là làm báo cáo } \\
\text { ADR trên giấy }\end{array}$ & 173 & 73,62 & 178 & 75,74 & 166 & 70,64 & 0,454 \\
\hline
\end{tabular}

\section{BÀN LUÂ̂N}

Nghiên cứu khảo sát đồng thời kiến thức, thái độ và thực hành báo cáo $A D R$ tại 3 bệnh viện đa khoa tuyến tỉnh. Bộ câu hỏi khảo sát được NVYT trả lời bằng Google forms, sử dụng điện thoại di động hoặc máy tính nên đảm bảo sự thuận tiện cho NVYT và người thu thập số liệu. Kết quả phỏng vấn NVYT bằng bộ câu hỏi cho thây tỷ lệ nhận thức đúng khái niệm $A D R$ còn thấp, $34,47 \%$ NVYT ở bệnh viện 3 , và giảm dần ở 2 bệnh viện còn lại là $29,36 \%$ và $27,44 \%$. Tuy nhiên, kết quả này cao hơn so với kết quả khảo sát thực hiện tại 10 bệnh viện đa khoa tuyến tỉnh trước đó năm 2016 (22,34\%)[6]. Bên cạnh đó phần lớn NVYT đều nhận thức được tầm quan trọng của việc báo cáo ADR (99,86\% NVYT tham gia khảo sát). Tỷ lệ này cao hơn so với kết quả nghiên cứu thực hiện tại Ấn Độ [7]. Việc hiểu đúng khái niệm $A D R$ và nhận thức vai trò của báo cáo tự nguyện giúp phát hiện kịp thời các vấn đề liên quan đến sử dụng thuốc trong thực hành.

Theo quy định của Bộ Y tế, NVYT cần báo cáo tối thiểu các thông tin gồm có: Thông tin về người bệnh; Thông tin về phản ứng có hại; Thông tin về thuốc nghi ngờ; Thông tin về người và đớn vị báo cáo [1]. 72,77\% NVYT ở BV 1 có nhận thức đầy đủ về các thông tin tối thiểu này trong khi đó 2 bệnh viện còn lại là: $66,38 \%$ và $58,30 \%$. Kết quả về Thời gian gửi báo cáo, đối với báo cáo nghiêm trọng, NVYT trả lời đúng có tỷ lệ rất cao, trung bình $96,53 \%$ tại cả 3 bệnh viện. Nhưng đối với báo cáo không nghiêm trọng, tỷ lệ trả lời đúng khá thấp, ở BV 2 chỉ đạt $6,04 \%$. Như vậy cần phải nâng cao hơn nửa nhận thức của các NVYT trong vấn đề báo cáo ADR mới có thể thúc đẩy được hoạt động báo cáo. Việc nhận thức đúng đắn về báo cáo $A D R$ có vai trò quan trọng trong thực hành chuyên môn của NVYT, góp phần quan trọng nâng cao số lượng cũng như chất lượng báo cáo. Trong nghiên cứu này $73,48 \%$ NVYT được khảo sát trả lời đã từng gặp $A D R$ song chỉ có $49,08 \%$ NVYT trả lời đã báo cáo $A D R$. Thực trạng báo cáo thấp hơn so với thực tế cũng được nghiên cứu tại Nepal có kết quả tương ứng là $74,8 \%$ và $20,1 \%$ [8]. Thực trạng này cũng có thể lý giải bởi các nguyên nhân chính khiến NVYT không làm báo cáo ADR như trong kết quả là "Phản ứng nhe không đáng để báo cáo" $(45,11 \%$ ở $\mathrm{BV} 1$ và̀ $41,70 \%$ ở BV 2) và "Không biết cách báo cáo" (48,51\% ở BV 3). Kết quả trên tương đồng với nghiên cứu thực hiện năm 2015 tại 3 bệnh viện đa khoa tuyến tỉnh [5]. Bên cạnh đó, "Khó xác định thuốc nghi ngờ" và "Khó xác định mức độ nghiêm trọng của $A D R^{\prime \prime}$ cũng là các rào cản dẫn tới tỷ lệ báo cáo thấp do đó cần hỗ trợ cho các NVYT trong hoạt động báo cáo ADR thông qua các hình thức đào tạo, tập huấn. Tuy nhiên một số các lý do liên quan đến thái độ của NVYT: "Khối lượng công việc nhiều nên hay quên báo báo", "Mất thời gian", "Lười chưa có trách nhiệm".

"Đào tạo tập huấn về $A D R$ " và "Phối hợp bác sĩ, dược sĩ và điều dưỡng để hỗ trợ báo cáo ADR" là 2 hình thức được NVYT lựa chọn với tỷ lệ cao nhất khi đề xuất giải pháp nâng cao hoạt động báo cáo $A D R$. Đây cũng là các đề xuất của NVYT đã được đề cập tới trong các nghiên cứu trước đây $[6,8]$. Kết quả nghiên cứu cho thây các bệnh viện, cơ quan quản lý và Trung tâm quốc gia về Thông tin thuốc và theo dõi phản ứng có hại của thuốc cần tổ chức đào tạo và hướng dẫn về văn bản quy định giám sát $A D R$, xác định thuốc nghi ngờ và ADR nghiêm trọng, đặc biệt là mỗi bệnh viện cần xây dựng quy trình báo cáo phù hợp.

\section{KẾT LUÂN}

Nhận thức đầy đủ về định nghĩa $A D R$ theo WHO của NVYT tuy còn thấp (215/705 NVYT) song đa số NVYT cho rằng báo cáo $A D R$ là một trong những hoạt động chuyên môn quan trọng.

$73,48 \%$ NVYT trả lời đã từng gặp $A D R$ tuy nhiên chỉ có $49,08 \%$ đã từng báo cáo $A D R$. Phản ứng nhe không đáng để báo cáo và Không biết cách báo cáo là những nguyên nhân thường gặp mà NVYT không làm báo cáo.

Giải pháp giúp nâng cao số lượng và chất lượng báo cáo $A D R$ được NVYT đề xuất nhiều nhất là "đào tạo tập huấn về $A D R$ " và "phối hợp bác sĩ, dược sĩ và điều dưỡng để hỗ trợ báo cáo $A D R^{\prime \prime}$, đồng thời kết hợp nhiều hình thức báo cáo hơn.

\section{TÀI LIẸU THAM KHẢO}

1. Bộ Y tế (2013), Quyết định 1088/QĐ-BYT ngày 4 tháng 4 năm 2013, ban hành hướng dẫn hoạt 
động giám sát phản ứng có hại của thuốc (ADR) tai các cơ sở khám, chữa bệnh.

2. Bộ Y tế (2015), Hướng dẫn quốc gia về Cảnh giảc Dược, Nhà xuất bản Thanh Niên .

3. WHO (2003), WHO Toxicity Grading scale for determining the severity of adverse events

4. Trung tâm DI \& ADR Quốc gia TỔNG KẾT CÔNG TÁC BÁO CÁO ADR NÁM 2019

5. Trân Thị Lan Anh, Trân Ngân Hà và CS (2015) "Khảo sát kiến thức và thực hành của cán bô y tế vế báo cáo phản ứng có hại của thuốc tại 3 bệnh viện tuyến tỉnh", Tap chí Dước hoc, 55 (6) ), tr. 6-11

6. Nguyê̂n Thị Thanh Hướng, Nguyễn Phương
Chi và CS (2016) "Thực trang kiến thức, thái độ và thực hành của cán bố y tế vể báo cáo phản ứng có hai của thuốc tại mười bệnh viện đa khoa tuyến tỉnh", Tạp chí Dược học số 7, tr.2-5.

7. Asmatanzeem Bepari, et al (2020) "The comparative evaluation of knowledge, attitude, and practice of different health-care professionals about the pharmacovigilance system of India", Saudi Pharmaceutical Journal.

8. Santosh KC et al, "Attitudes among healthcare professionals to the reporting of adverse drug reactions in Nepal", BMC Pharmacology and Toxicology, 5, 2013, pages 14.

\title{
NGHIÊN CỨU NỒNG Độ DOPAMIN CÙNG CÁC CHẤT CHUYỂN HÓA CỦA DOPAMIN TRONG DICH NÃO TỦY VÀ MỐI LIÊN QUAN VỚI MỘT SỐ BIỂU HIỆN LÂM SÀNG Ở BÊ̂NH NHÂN MẮC BỆNH PARKINSON
}

\author{
Nguyễn Đức Thuận ${ }^{1}$, Nhữ Đình Sơn' ${ }^{1}$, Nguyễn Hũu Quang ${ }^{2}$, \\ Lê Văn Quân ${ }^{1}$, Hoàng Thị Dung ${ }^{1}$, Trịnh Văn Quỳnh ${ }^{1}$
}

\section{TÓM TẮT}

Muc tiêu: Nghiên cứu nồng độ dopamin cùng các chất chuyển hóa của dopamin (DOPAC) trong dịch não tủy và mối liên quan với một số biểu hiện lâm sàng ở bệnh nhân mắc bệnh Parkinson. Đối tượng và phương pháp: Tiến cứu, mô tả cắt ngang có so sánh với nhóm chứng. Phương pháp chọn mẫu: Chọn mẫu thuận tiện. Xét nghiệm định lượng nồng độ dopamin, DOPẢC dịch não tủy cho cả nhóm bệnh và nhóm chứng. Kết quả: Nồng đô dopamin dich não tủy ở nhóm chứng giá trị trung bình là $31,85 \pm 12,56 \mathrm{pg} / \mathrm{ml}$ trong khi ơ nhóm bệnh nhân Parkinson là $20,10 \pm 3,52 \mathrm{pg} / \mathrm{ml}$. Nồng độ DOPAC dịch não tủy ở nhóm chứng giá tri trung bình là $7,03 \pm 4,14 \mathrm{ng} / \mathrm{ml}$ trong khi ơ bênh nhóm bệnh nhân Parkinson là 3,75 $\pm 3,00 \mathrm{pg} / \mathrm{ml}$. Nồng độ dopamin, DOPAC dịch não tủy giảm dần từ giai đoạn bênh 1 đến giai đoạn 4,5. Sự khác biêt là có ý nghĩa thống kê $(p<0,001)$. Nồng độ dopamin, DOPAC dich não tủy giảm dần từ mức đồ bênh nhe đến mức độ nặng và rất nặng. Sự khác biệt là có ý nghĩa thống kế $(p<0,001)$. Nồng đợ dopamin, DOPAC dịch não tủy giảm dần từ không bị trầm cảm đến trầm cảm mức độ nhe, vừa và nặng. Sự khác biệt là có ý nghĩa thống kê $(p<0,05)$. Có sự tương quan nghịch có nghĩa thống kê giữa nồng độ dopamin dịch não tủy với thời gian mắc bệnh $(R=-0,764, p<0,001)$. Có sự tương quan nghich có nghĩa thống kê giữa nồng độ DOPAC dịch não tủy với thời gian mắc bệnh $(R=$ $0,690, p<0,001)$. Kết luận: Nghiên cứu chúng tôi cho thấy có sự giảm đáng kể nồng độ dopamin, DOPAC dịch não tủy ở bệnh nhân Parkinson so với

${ }^{1}$ Bệnh viện Quân y 103

${ }^{2}$ Trường đại hoc Buôn Ma Thuôt

Chịu trách nhiệm chính: Nguyển Đức Thuận

Email: nguyenducthuan@vmmu.edu.vn

Ngày nhận bài: 9.3.2021

Ngày phản biên khoa họ: 27.4.2021

Ngày duyệt bài: 10.5.2021 nhóm chứng, mức độ bệnh càng nặng, giai đoạn bệnh càng tăng thì nồng độ dopamin, DOPAC dịch não tủy càng giảm. Có Có sự tương quan nghịch có nghĩa thống kê giữa nồng độ dopamine, DOPAC dịch não tủy với thời gian mắc bênh.

Tư khóa: Bênh Parkinson; Nồng độ dopamine dịch não tủy; Nồng độ DOPAC dịch não tủy.

\section{SUMMARY}

RESEARCH OF THE CONCENTRATION OF DOPAMINE AND ITS METABOLITES IN THE CEREBROSPINAL FLUID AND ITS RELATIONSHIP WITH SOME CLINICAL MANIFESTATIONS IN PATIENTS WITH PARKINSON'S DISEASE

Objectives: To study the concentration of dopamine and its metabolites (DOPAC) in the cerebrospinal fluid (CSF) and its relationship with some clinical manifestations in patients with Parkinson's disease. Subjects and methods: Prospective, cross-sectional description with comparison with control group. Sampling method: Convenience sampling. Quantitative testing of dopamine and DOPAC levels of cerebrospinal fluid for both disease and control groups. Results: The mean concentration of dopamine in the control group was $31.85 \pm 12.56 \mathrm{pg} / \mathrm{ml}$ while in the Parkinson's group it was $20.10 \pm 3.52 \mathrm{pg} / \mathrm{ml}$. The mean DOPAC concentration of CSF in the control group was $7.03 \pm$ $4.14 \mathrm{ng} / \mathrm{ml}$ while in Parkinson's patients it was $3.75 \pm$ $3.00 \mathrm{pg} / \mathrm{ml}$. The concentration of dopamine, DOPAC of cerebrospinal fluid gradually decreased from stage 1 to stage 4.5. The difference is statistically significant $(p<0.001)$. The concentration of dopamine and DOPAC in the cerebrospinal fluid gradually decreased from mild disease to severe and very severe disease. The difference is statistically significant $(p<0.001)$. Dopamine levels, CSF DOPAC gradually decreased from no depression to mild, moderate and severe 